COLONIAL VIRGINIA'S PAPER MONEY REGIME, 1755-1774: A FORENSIC ACCOUNTING RECONSTRUCTION OF THE DATA

\author{
Farley Grubb \\ Working Paper 21785 \\ http://www.nber.org/papers/w21785 \\ NATIONAL BUREAU OF ECONOMIC RESEARCH \\ 1050 Massachusetts Avenue \\ Cambridge, MA 02138 \\ December 2015
}

The views expressed herein are those of the author and do not necessarily reflect the views of the National Bureau of Economic Research.

NBER working papers are circulated for discussion and comment purposes. They have not been peerreviewed or been subject to the review by the NBER Board of Directors that accompanies official NBER publications.

(C) 2015 by Farley Grubb. All rights reserved. Short sections of text, not to exceed two paragraphs, may be quoted without explicit permission provided that full credit, including $\odot$ notice, is given to the source. 
Colonial Virginia's Paper Money Regime, 1755-1774: a Forensic Accounting Reconstruction of the Data Farley Grubb

NBER Working Paper No. 21785

December 2015

JEL No. C82,E51,N11

\begin{abstract}
I reconstruct the data on Virginia's paper money regime using forensic accounting techniques. I correct the existing data on the amounts authorized and outstanding. In addition, I reconstruct yearly data on previously unknown aspects of Virginia's paper money regime, including printings, net new emissions, redemptions and removals, denominational structures, expected tax revenues, and specie accumulating in the treasury for paper money redemption. These new data form the foundation for narratives written on the social, economic, and political history of Virginia, as well as for testing models of colonial paper money performance.
\end{abstract}

Farley Grubb

University of Delaware

Economics Department

Newark, DE 19716

and NBER

grubbf@udel.edu 


\section{Colonial Virginia's Paper Money Regime, 1755-1774: a Forensic Accounting Reconstruction of the Data}

I reconstruct the data on Virginia’s paper money regime using forensic accounting techniques. I correct the existing data on the amounts authorized and outstanding. In addition, I reconstruct yearly data on previously unknown aspects of Virginia's paper money regime, including printings, net new emissions, redemptions and removals, denominational structures, expected tax revenues, and specie accumulating in the treasury for paper money redemption. These new data form the foundation for narratives written on the social, economic, and political history of Virginia, as well as for testing models of colonial paper money performance.

In 1755, Virginia and Georgia became the last of the 13 colonies to emit paper money.

The performance of Virginia's paper money regime is central to the history of the period. It was at the center of the conflict with the Crown over colonial monetary powers and provided justification for Parliament passing the Currency Act of 1764 (4 Geo III c. 34). This conflict contributed to revolutionary sentiments. Virginia’s paper money regime was also a point of contention in Virginia politics. Irregular activities by Virginia's treasurer occupied a substantial amount of political attention. Virginia's administrative structure was altered as a result. ${ }^{2}$

Virginia had the second largest free population of the 13 colonies (Carter, et al. 2006, v. 5, p. 652). Why Virginia took so long to initiate its own paper money regime is curious. Part of Virginia's delay may be due to the relative efficiency of its commodity "tobacco" money which was commonly used in domestic transactions and to pay local taxes. Prior to emitting paper money, Virginia’s media of exchange consisted of barter, typically involving book-credit and tobacco-often in the form of claims to tobacco or tobacco notes; personal bills of exchange and

\footnotetext{
${ }^{1}$ Professor and NBER Research Associate, Economics Department, University of Delaware, Newark, DE 19716. Email: grubbf@udel.edu. Web-page: http://www.lerner.udel.edu/faculty-staff/faculty/farley-grubb. A preliminary version was presented at Vanderbilt University, Oct. 2015. The author thanks the participants for helpful comments and Tracy McQueen for editorial assistance.

${ }^{2}$ Brock (1975, pp. 465-527); Ernst (1973); Greene and Jellison (1961); Journal of the Commissioners for Trade and Plantations from January 1759 to December 1763 (1970, pp. 330-5); Labaree (1966, v. 9, pp. 131-53); Mays (1952, v. 1, pp. 174-208, 358-85).
} 
promissory notes; and specie coins. The composition of this media is unknown, though specie coins were considered relatively scarce.

Budgetary crises caused by wars typically pushed colonies into paper money systems (Grubb 2016). Virginia did not face such a crisis until the Seven Year's War. The immediate and large spending demands of Virginia’s participation in the Seven Year's War swamped Virginia's ability to raise enough taxes immediately to meet these expenses (Brock 1975, pp. 466-9, 476). As a result, the Virginia legislature authorized 614,797 "Virginia pounds" ( $\left.£_{\mathrm{VA}}\right)$ worth of paper money to be printed between 1755 and 1774 .

Paper money was created by colonial legislatures and directly spent by those legislatures through their respective treasuries. Legislature-issued, colony-specific paper monies were the only paper monies in circulation in colonial America. No public or private incorporated banks issuing paper banknotes backed by fractional specie reserves, with said banknotes redeemable at face value in specie at the issuing bank, existed in colonial America (Hammond 1991, pp. 3-67).

The amount of paper money the Virginia legislature maintained in public circulation is foundational data. The political, social, and economic narratives of Virginia’s late colonial history, and the history of colonial America over its last quarter century, are erected upon, and must be consistent with, that data. Yet, no one alive today knows where the quantitative data currently in use on Virginia’s paper money regime originates (Carter, et al. 2006, v. 5, pp. 6926). It is mysterious data that could be, for all anyone knows, totally made up.

This is a methodological essay. Scholars need to know how quantitative data are created. They need to know where these data are reasonably solid and trustworthy—closely linked to primary source observations, and where they are highly constructed and fragile—-being based on supposition, assumption, and conjecture. In particular, scholars need to know where the data 
suffer error variance in their construction, what the source of that error variance is, the magnitude of that error variance, and what alternative data constructions are possible. Scholars who craft the political, social, and economic narratives of Virginia's late colonial history, as well as economists who test models of colonial paper money, depend on that knowledge.

I will show how the quantitative data on Virginia’s colonial paper money are constructed, and in the process produce better data than currently exists. I will also construct yearly data on previously uncharted aspects of Virginia’s paper money regime, including on paper money printings, net new emissions, redemptions and removals, denominational structures, expected tax revenues, and the specie accumulating in the treasury for paper money redemption. Throughout, the goal is to show scholars the nitty-gritty of how it is done-to lay bare the assumptions made so that the reasonableness of the data constructions may be compared with possible alternatives.

The essay proceeds as follows: First, I assess the current quantitative data on colonial Virginia's paper money regime and compare it with my final reconstructed data. Second, I proceed step-by-step through how these data are constructed. I start with emissions, proceed through redemptions and removals, and end with a final data series of paper money in public circulation. Third, I present data on the denominational structure of Virginia’s paper money and estimate the medium in which the taxes imposed by paper money acts were paid. I also estimate the amounts of specie and tobacco monies accumulating in the treasury to be used to redeem paper money. Lastly, I use these data to reassess the John Robinson treasury scandal that rocked Virginia politics in the mid-1760s.

Virginia referred to its paper money as treasury notes. Other colonies referred to their paper monies as bills of credit. While treasury notes were the same as bills of credit, I will refer to Virginia’s paper money throughout as notes rather than bills in keeping with Virginia’s 
terminology (Hening 1969, v. 7, p. 353).

\section{Mysterious Data}

Historical Statistics (Carter, et al. 2006, v. 5, pp. 692-6) is the current go-to place for data on the amount of colonial Virginia paper money in circulation each year. If one tracks back through the citations and sources listed, the hypothesis that these numbers are made up cannot be rejected. They are not observations, even though they are seemingly presented as such. They are not estimates or interpolations, as that would indicate that some methodology or calculating construction was used, and none is offered. Where these numbers come from is a mystery.

In the Historical Statistics, the numbers for Virginia are taken from Brock (1992, p. 116). John J. McCusker compiled the numbers in the Historical Statistics, and while he cites several sources, the numbers are identical to those in Brock (1992, p. 116) and not to those in any other source. $^{3}$ Of the sources cited, only Brock (1992, p. 116) and Ernst (1972, p. 370) report numbers on the amount of Virginia notes in circulation. Brock (1992, p. 116) cites Ernst (1973, pp. 7 and 356). However, no such numbers exist in Ernst on those pages. Ernst (1973, p. 370) does report some numbers for the amounts of Virginia paper money in circulation, but only for 9 of the 20 years covered by Brock. These numbers are also not the same as those in Brock (1992, p. 116) or in the Historical Statistics. McCusker concluded that "Brock (1992), p. 115, seems to have interpolated some of his data but this is not made explicit," — a generous assessment (Carter et al. 2006, v. 5, p. 695).

Brock (1992, p. 116) was not published by Brock, but by Ron Michener well after Brock’s death using Brock’s surviving notes. A close look at Brock (1975, pp. 476-7 [original 1941]) shows that Brock had created these numbers on Virginia’s notes in circulation prior to 1941, as he graphed these numbers on those pages. He did not, however, present the actual

\footnotetext{
${ }^{3}$ McCusker mistakenly cites Brock (1992, p. 115) whereas the numbers are actually on p. 116.
} 
numerical values. Brock (1975, p. 475) describes the graph as "Some idea" of the sums outstanding and not as an estimate or as observations of the sums outstanding.

I assume the numbers in Brock (1992, p. 116), as well as in Ernst (1973, p. 370), are not totally fabricated, but came from some investigation of evidence in primary sources. I use three primary sources in my forensic reconstruction of the data, namely the statutory paper money acts (Hening 1969); the treasury accounts as recorded in the Journals of the House of Burgesses (Kennedy 1906a, pp. 64-6, 108, 118-20, 124-8, 154-6, 283-5, 303; 1906b, pp. 72, 217-8; 1907, pp. 143, 171, 176-8, 356-7; McIlwaine 1908, pp. 15, 36-7, 115-6, 171-2, 249-50; 1909, pp. 388, 458, 487-90); and the letters published in the Virginia Gazette by the post-1765 treasurer Robert Carter Nicholas (William and Marry College Quarterly Historical Magazine 1912, pp. 227-62). Brock and Ernst clearly consulted these three primary sources to construct their numbers. The mystery of how they used and interpreted these sources is sorted out here.

While the statutory paper money acts appear to offer rather straightforward data that can be simply picked out and reported, there are subtle issues of interpretation that can lead scholars astray. More significantly, the statutory paper money acts by themselves do not yield the amounts of paper money in circulation. Information from the treasury accounts must be added. Alas, the treasury accounts are incomplete, disorganized, irregularly reported, chaotic and inconsistent in presentation structure, and unclear in the use of common terminology. For example, what is meant in the treasury accounts by the term "issued" and the term "in circulation” are not what we commonly understand by such words today.

An extensive forensic accounting reconstruction of these accounts is required to make sense of them. This reconstruction is provided below. The forensic reconstruction also puts key terminologies used in the treasury accounts into their proper historical context, thereby 
deciphering their usage by contemporaries. Forensic accounting uses existent records to reconstruct the accounts of interest to a standard sufficient to meet legal criteria. Given that the records are legislative, that standard is appropriate. This reconstruction relies on tracking internal consistencies and coherences across the existent records, paying close attention to the execution details embedded in the relevant laws, and using reasonable inferences to fill in missing data. ${ }^{4}$

While we may never know how Brock and Ernst created their numbers, my forensic reconstruction of Virginia’s paper money regime shows what Brock and Ernst likely did, along with what they likely missed. In the process, additional information beyond the amount of paper money authorized by statute and the amount in circulation are recovered. The forensic reconstruction process also shows where the data are solid and where the data are fragile-giving scholars a feel for the error variance in the paper money data in the historical record.

\section{Preview}

Figure 1 presents my preliminary and final forensic reconstruction of the amounts of Virginia's notes in public circulation along with those numbers presented by Brock and Ernst. My preliminary and final reconstructions are reasonably close to the numbers provided by Brock and Ernst. If my forensically reconstructed data are rejected, including their component parts, then the data presented by Ernst and Brock, a.k.a. the Historical Statistics data, must also be rejected, leaving no usable data on this topic.

While my reconstructed data are reasonably close to that of Brock and Ernst, Table 1 shows that in some years the percentage deviations of Brock's numbers and Ernst's numbers from my final reconstructed numbers are substantial. As such, my final reconstruction makes important corrections to the Brock and Ernst data. The substantial deviations of Brock and Ernst

\footnotetext{
${ }^{4}$ For general information on forensic accounting, see Crumbley, Heitger, and Smith (2013); http://www.forensicaccounting.com.
} 


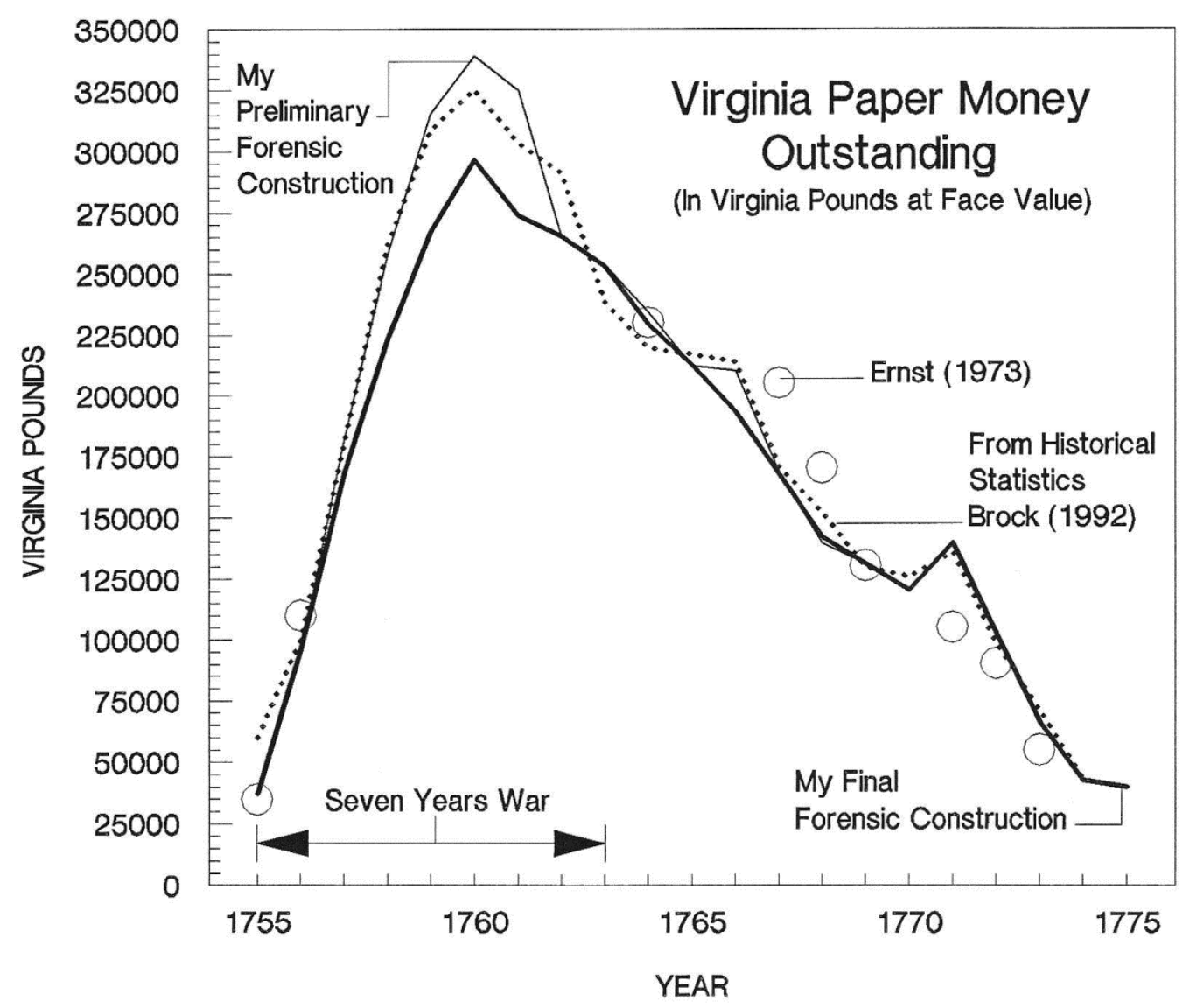

Figure 1. The Quantity of Virginia Paper Money Outstanding

Sources: Table 1; Carter, et al (2006, v. 5, p. 693); Ernst (1973, p. 370). My preliminary forensic construction uses column (3) instead of column (4) in Table 4 to estimate notes outstanding.

from my reconstructed data in Table 1 are due to oversights by these scholars when looking at the primary sources and to the fact that they did not reconstruct tax revenues.

Brock substantially overstates the amount in circulation in 1755 . He missed the fact that $3,960 £_{\mathrm{VA}}$ authorized to be emitted in 1755 was recorded in the treasury accounts as never emitted, and missed the fact that $18,861 £_{\mathrm{VA}}$ authorized to be emitted in 1755 was recorded in the treasury accounts as not emitted in 1755, but in a subsequent year. By contrast, Ernst must have incorporated these facts as he gets the amount for 1755 correct—within the rounding exercise he employs. The other deviations of Brock from my reconstructed data are the result of timing placements regarding when amounts reported as emitted and redeemed were actually put into 
Table 1 Amount of Virginia Notes in Circulation, 1755-1774: Various Sources

\begin{tabular}{|c|c|c|c|c|c|c|}
\hline \multirow[b]{2}{*}{ Year } & \multirow{2}{*}{$\begin{array}{l}\text { (1) } \\
\text { Historical } \\
\text { Statistics }^{\mathrm{a}}\end{array}$} & \multirow{2}{*}{$\begin{array}{c}(2) \\
\text { Brock } \\
(1992)^{\mathrm{C}}\end{array}$} & \multirow{2}{*}{$\begin{array}{l}\text { (3) } \\
\text { Ernst } \\
(1973)^{\mathrm{e}}\end{array}$} & \multirow{2}{*}{$\begin{array}{c}\text { (4) } \\
\text { My Final } \\
\text { Reconstruction }\end{array}$} & \multicolumn{2}{|c|}{ Percentage Deviation of- } \\
\hline & & & & & $\begin{array}{c}\text { Column (2) } \\
\text { from (4) }\end{array}$ & $\begin{array}{c}\text { Column (3) } \\
\text { from (4) }\end{array}$ \\
\hline & $£_{\mathrm{VA}}$ & $\varepsilon_{\mathrm{VA}}$ & $£_{\mathrm{VA}}$ & $\varepsilon_{\mathrm{VA}}$ & $\%$ & $\%$ \\
\hline 1755 & 60,000 & 60,000 & 35,000 & 37,179 & 61.38 & -5.86 \\
\hline 1756 & 100,000 & 99,963 & 110,000 & 95,582 & 4.58 & 15.08 \\
\hline 1757 & 180,000 & 179,962 & & 167,605 & 7.37 & \\
\hline 1758 & 261,500 & 261,523 & & 223,318 & 17.11 & \\
\hline 1759 & 308,800 & 308,789 & & 266,949 & 15.67 & \\
\hline 1760 & 325,000 & 325,044 & & 296,266 & 9.71 & \\
\hline 1761 & 303,400 & 303,360 & & 273,507 & 10.91 & \\
\hline 1762 & 291,100 & 291,107 & & 265,286 & 9.73 & \\
\hline 1763 & $238,400^{b}$ & $238,439^{d}$ & & 253,120 & -5.80 & \\
\hline 1764 & $219,500^{b}$ & $219,508^{d}$ & 230,000 & 229,322 & -4.28 & 0.30 \\
\hline 1765 & $216,600^{b}$ & $216,640^{\mathrm{d}}$ & & 212,373 & 2.01 & \\
\hline 1766 & 213,800 & 213,771 & & 193,225 & 10.63 & \\
\hline 1767 & 170,400 & 170,420 & 205,000 & 167,474 & 1.76 & 22.41 \\
\hline 1768 & 151,400 & 151,408 & 170,000 & 141,723 & 6.83 & 19.95 \\
\hline 1769 & 129,900 & 129,875 & 130,000 & 130,677 & -0.61 & -0.52 \\
\hline 1770 & 125,400 & 125,426 & & 120,136 & 4.40 & \\
\hline 1771 & $135,300^{b}$ & $135,305^{d}$ & 105,000 & 139,192 & -2.79 & -24.56 \\
\hline 1772 & 98,300 & 98,336 & 90,000 & 102,630 & -4.18 & -12.31 \\
\hline 1773 & 70,700 & 70,695 & 55,000 & 66,068 & 7.00 & -16.75 \\
\hline 1774 & 43,400 & 43,377 & & 42,713 & 1.55 & \\
\hline
\end{tabular}

Sources: Carter, et al. (2006, v. 5, p. 693); Ernst (1973, p. 370); Table 6 below.

Notes: $£_{\mathrm{VA}}=$ Virginia paper pounds at face value.

${ }^{\mathrm{a}}$ Rounded to the nearest 100.

b Identified as interpolated values.

${ }^{\mathrm{c}}$ End of year values are reported.

d Placed in brackets with no explanation as to why.

e Rounded to the nearest 5,000.

and taken out of circulation, which is partly due to how tax revenues are reconstructed and used.

The substantial deviations of Ernst from my reconstructed data in Table 1 are the result of several oversights by Ernst. While Ernst must have consulted the treasury accounts, he simply reports the numbers found rather than interpreting their meaning. For example, he reports a number for 1756 that assumes that no redemptions took place in 1756 . The redemption and removal of the first emission was scheduled for mid-1756. Its redemption was not reported in the treasury accounts until early in 1757. Ernst must have assumed, given the reporting year, that 
none was redeemed in 1756. Most taxes to redeem notes, as Ernst himself points out (Ernst 1973, p. 186), were collected in the fall, with total collections not reported until the next spring. Therefore, it is unlikely that this emission was not primarily redeemed in 1756.

Ernst's numbers in Table 1 for 1767-1769 and 1772-1773 come directly from statements in the treasury accounts about the amount of notes in circulation. ${ }^{5}$ Again, Ernst simply reports the numbers he ran across. Such reporting results in three errors of interpretation. First, these statements were typically made early in the year and thus refer to notes removed in the latter part of the prior year. Thus, these statements are off by one year and the amounts reported should be placed in the prior year. Second, the treasury accounts explicitly refer to these amounts in circulation as being only for “old” notes, meaning notes issued before 1769 . They do not include the 40,000 $£_{\mathrm{VA}}$ "new” notes emitted in 1769 and 1771. Thus, the amounts Ernst lists after 1769 are biased low. Finally, the treasury accounts construct these numbers by taking all notes printed and then subtracting all notes burned. To the extent that this construction fails to subtract notes sitting idle in the treasury, unburned and un-emitted, it overstates the amounts actually in public circulation, especially pre-1769. Thus, pre-1769, Ernst's numbers are biased high.

What follows is my forensic reconstruction of the data using the primary sources. It will show in detail what Brock, and to a lesser extent Ernst, must have done to create their data, and what they failed to consider. It also gives scholars a sense of what aspects of this estimation are more exact to observation and what are highly constructed. I proceed from the most solid and trustworthy evidence in the primary sources through the forensically reconstructed data that relies directly on that solid and trustworthy evidence to the most fragile or "constructed” data that relies on reasonable inference, back-projection, interpolation, and data cloning. This is done so scholars can get a sense of the size and location of the error variance in measurement and so

\footnotetext{
${ }^{5}$ I have no idea where his numbers for 1764 and 1771 come from.
} 
what data they can trust as exact and what data they should take only with a margin of error, as well as what that margin might be.

\section{The Forensic Reconstruction of Colonial Virginia's Paper Money Accounts}

Ultimately, the number desired is the amount of paper money in public circulation each year. It is this amount that influences behavior and thus historical processes and outcomes. Such numbers, however, cannot be found in the surviving records of colonial Virginia. One cannot just go to a primary source and copy down such data. The few times that colonial Virginia documents mention amounts of paper money in circulation they did not mean what is commonly understood as being "in circulation.” As such, this data has to be constructed out of the information that has survived. To find the amounts of paper money in circulation each year, one needs to establish the amounts of new paper money emitted into public hands each year, then subtract from that the amounts of paper money removed from the public each year, and then chart the total accumulation or de-accumulation of paper money over time as a result of this yearly emissionredemption-removal process.

\section{a. New Emissions Authorized by Statutory Law}

The data construction process starts with identifying how much new paper money was emitted each year by the legislature. Such information can be derived from the statutory laws that authorized paper money emissions. While this information comes from the most complete and clear surviving primary source, it still is not free from scholarly misinterpretation. Simply copying down data in this source can lead one astray. The statutory laws on paper emissions report total paper money authorized to be printed and total paper money authorized to be emitted. They are not the same totals. The difference for Virginia comes from one-for-one swaps of new paper money for old. Such one-for-one swaps do not affect the total amount of paper money in 
public circulation. To get to the total amount of paper money in public circulation, information on net new emissions of paper money rather than total printings of paper money is needed.

Table 2 lists the 16 paper money acts, their legislative session dates, and the total printed versus net new emissions of paper money authorized by each act. These two numbers are the same for each act except for emissions \#6 and \#16. Emission \#6 included 95,000 $£_{\mathrm{VA}}$ to be swapped one-for-one with emissions \#2, \#3, and \#4. Emission \#16 was all to be swapped onefor-one with what was left outstanding from emissions \#14 and \#15. These amounts must be removed to get the total net new emissions authorized.

Table 2 shows that Ernst (1973, p. 370) reported total printings not net new emissions. Given that most readers assume that the numbers reported are net new emissions, Ernst's data overstates total net new emissions by 27 percent. A similar judgment can be made of the data reported in the 1912 William and Mary College Quarterly Historical Magazine. By contrast, the data reported by Brock (1975, pp. 476-7) is for net new emissions and not total printings. Brock, however, does not report emissions after 1762 and excludes 4,963£ $£_{\mathrm{VA}}$ from emission \#6, erroneously counting that amount as part of the one-for-one currency swap rather than as part of the new emission. The $4,963 £_{\mathrm{VA}}$ amount were new emission \#6 notes used to pay the accrued interest on emissions \#2, \#3, and \#4 when those notes were swapped for emission \#6 notes. They are part of the net new emission of emission \#6 notes. As such, Brock understates total net new emissions by 9 percent.

One last adjustment has to be done to the net new emissions authorized in Table 2. While statutory law authorized only $10,000 £_{\mathrm{VA}}$ for emission \#5, 12,000 $£_{\mathrm{VA}}$ was actually printed and emitted according to the House of Burgesses (McIlwaine 1909, p. 490). While statutory law is regarded as superior in authority to legislative statements, treasurer accounts corroborate this 
Table 2 Virginia’s Paper Money Acts in Statutory Law, 1755-1774

\begin{tabular}{|c|c|c|c|c|c|c|c|}
\hline \multirow{3}{*}{$\begin{array}{l}\text { Paper } \\
\text { Money } \\
\text { Acts }\end{array}$} & \multirow{3}{*}{$\begin{array}{l}\text { Session } \\
\text { Month } \\
\text { and Year } \\
\text { Enacted }\end{array}$} & \multicolumn{2}{|c|}{$\begin{array}{l}\text { Amounts Authorized } \\
\text { by Statutory Law }\end{array}$} & \multirow{3}{*}{$\begin{array}{l}\text { Legislated } \\
\text { Final } \\
\text { Redemption } \\
\text { Date }\end{array}$} & \multicolumn{3}{|c|}{ Amounts as Reported in: } \\
\hline & & To be & Net New & & Ernst & Brock & William and Mary \\
\hline & & Printed & Emissions & & (1973) & (1941) & Quarterly (1912) \\
\hline & & $\varepsilon_{\mathrm{VA}}$ & $\varepsilon_{\mathrm{VA}}$ & & $£_{\mathrm{VA}}$ & $£_{\mathrm{VA}}$ & $£_{\mathrm{VA}}$ \\
\hline \#1 & May 1755 & 20,000 & 20,000 & 30 June 1756 & 20,000 & 20,000 & 20,000 \\
\hline \#2 & Aug. 1755 & 40,000 & 40,000 & 30 June 1760 & 40,000 & 40,000 & 40,000 \\
\hline \#3 & Mar. 1756 & 25,000 & 25,000 & 30 June 1760 & 25,000 & 25,000 & 25,000 \\
\hline$\# 4$ & Mar. 1756 & 30,000 & 30,000 & 30 June 1760 & 30,000 & 30,000 & 30,000 \\
\hline \#5 & Mar. 1756 & 10,000 & 10,000 & 15 Dec. 1757 & 12,000 & 12,000 & 10,000 \\
\hline$\# 6$ & Apr. 1757 & 179,963 & 84,963 & 1 Mar. 1765 & 179,963 & 80,000 & 179,963 \\
\hline \#7 & Mar. 1758 & 32,000 & 32,000 & 1 Mar. 1765 & 32,000 & 32,000 & 32,000 \\
\hline$\# 8$ & Sept. 1758 & 57,000 & 57,000 & 14 Sept. 1766 & 57,000 & 57,000 & 57,000 \\
\hline \#9 & Feb. 1759 & 52,000 & 52,000 & 20 Apr. 1768 & 52,000 & 52,000 & $57,000^{\mathrm{a}}$ \\
\hline$\# 10$ & Nov. 1759 & 10,000 & 10,000 & 20 Oct. 1769 & 10,000 & 10,000 & 10,000 \\
\hline \#11 & Mar. 1760 & 20,000 & 20,000 & 10 Oct. 1768 & 20,000 & 20,000 & 20,000 \\
\hline$\# 12$ & May 1760 & 32,000 & 32,000 & 20 Oct. 1769 & 32,000 & 32,000 & 32,000 \\
\hline \#13 & Mar. 1762 & 30,000 & 30,000 & 20 Oct, 1769 & 30,000 & 30,000 & 30,000 \\
\hline$\# 14$ & Nov. 1769 & 10,000 & 10,000 & 21 Nov. 1771 & 10,000 & & 10,000 \\
\hline \#15 & July 1771 & 30,000 & 30,000 & 10 Dec. 1775 & 30,000 & & 30,000 \\
\hline$\# 16$ & Mar. 1773 & 36,834 & 0 & 1 June 1774 & 36,834 & & 36,834 \\
\hline Total & & 614,797 & 482,963 & & 616,797 & 440,000 & $619,797^{\mathrm{a}}$ \\
\hline
\end{tabular}

Sources: Brock (1975, pp. 476-7); Ernst (1973, p. 370); Hening (1969, v. 6, pp. 461-81, 521-30; v. 7, pp. 9-25, 2633, 46-54, 69-87, 163-9, 171-9, 255-65, 331-7, 347-58, 357-63, 493-502; v. 8, pp. 342-8, 493-503, 647-51); William and Mary College Quarterly Historical Magazine (1912, pp. 261-2).

Notes: $£_{\mathrm{VA}}=$ Virginia paper pounds at face value. See the text for construction adjustments to \#5.

${ }^{\mathrm{a}}$ This source lists $614,797 £_{\mathrm{VA}}$ as the total, which would be consistent with a typo existing in this sources statement about emission \#9, with the 7 being a typo for a 2 .

alternative total. On three different occasions across two different treasurers, the treasury accounts says that 539,963£ $\mathrm{VA}$ were emitted from 1755 through 1762 (Kennedy 1906a, pp. 119, 155; William and Mary College Quarterly Historical Magazine 1912, p. 234). Summing the authorized numbers in Table 2 indicates that these treasury accounts are reporting total printings as the amounts "issued" and not net new emissions.

The summing of authorized amounts printed in Table 2 is $2,000 £_{\mathrm{VA}}$ less than that reported in the treasury accounts for that period. The only mention of this extra $2,000 £_{\mathrm{VA}}$ is in regard to emission \#5 (Mcllwaine 1909, p. 490). Given this corroboration and coherence across the existent records, $12,000 £_{\mathrm{VA}}$ will be taken as the correct amount for emission \#5 (see also 
Table 8 below). Both Ernst and Brock report emission \#5 as being for 12,000 $£_{\mathrm{VA}}$ rather than the $10,000 £_{\mathrm{VA}}$ as authorized by statutory law. These two scholars must have been examining the treasury accounts as reported in the Journals of the House of Burgesses to construct their data on paper money, as that source is the only place the $12,000 £_{\mathrm{VA}}$ figure can be found.

\section{b. Net New Emissions Actually Put Into Public Circulation}

In the absence of contrary evidence in the treasury accounts, I assume that notes went into public circulation in the year they were authorized by legislative statute. The dates printed on the notes averaged only one month later than the assembly session authorizing the respective notes (Newman 2008, pp. 437-43). Given this observation, and the fact that new authorizations came yearly and often sub-yearly before 1761, it is a reasonable assumption.

Table 3 uses the information stated in the treasury accounts to make two adjustments to turn the net new amounts authorized into net new emissions actually put into public circulation. First, the treasury accounts state that certain authorized amounts from emissions \#1 and \#2 were never spent out of the treasury, but sat there, and were eventually burned without ever being emitted. Column (2) of Table 3 lists those sums and the authorized emissions from which they must be subtracted.

The amount identified in column (2) of Table 3 for emission \#2 in 1755, however, must

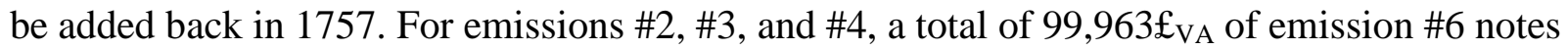
were authorized to be swapped for emission \#2, \#3, and \#4 notes in public circulation and to pay off the accrued interest on those notes to that point. Only 93,604£ $£_{\mathrm{VA}}$ of emissions \#2, \#3, and \#4 were emitted into public circulation, thus the interest portion of the amount authorized was $6,359 £_{\mathrm{VA}}$. In effect, the "missing” un-emitted notes from emission \#2 are added back in to the total emitted via interest payments above the 93,604£ $£_{\mathrm{VA}}$ currency swap. 
Table 3 Net New Emissions Actually Put Into Public Circulation, 1755-1774

\begin{tabular}{|c|c|c|c|c|c|c|c|c|c|}
\hline \multirow[b]{2}{*}{ Year } & \multicolumn{2}{|c|}{\begin{tabular}{l}
\multicolumn{1}{c}{$(1)$} \\
Net New \\
Amounts \\
Authorized
\end{tabular}} & \multicolumn{2}{|c|}{\begin{tabular}{l}
\multicolumn{1}{c}{$(2)$} \\
Minus Amounts \\
Never Emitted \\
to the Public
\end{tabular}} & \multicolumn{2}{|c|}{\begin{tabular}{l}
\multicolumn{1}{c}{$(3)$} \\
Plus and Minus \\
When Emitted \\
to the Public
\end{tabular}} & \multirow[b]{2}{*}{ Year } & \multirow{2}{*}{$\begin{array}{l}\quad(4) \\
\text { Net New Emissions } \\
\text { Actually Put Into } \\
\text { Public Circulation } \\
\qquad \varepsilon_{\mathrm{VA}}\end{array}$} & \multirow{2}{*}{$\begin{array}{l}(5) \\
\text { Accumulation } \\
\text { If None Were } \\
\text { Removed } \\
£_{\mathrm{VA}}\end{array}$} \\
\hline & Em \# & $£_{\mathrm{VA}}$ & Em \# & $£_{\mathrm{VA}}$ & Em \# & $\varepsilon_{\mathrm{VA}}$ & & & \\
\hline \multirow[t]{2}{*}{1755} & 1 & 20,000 & 1 & $-3,960$ & & & & & \\
\hline & 2 & 40,000 & 2 & $-1,396$ & 2 & $-17,465$ & 1755 & 37,179 & 37,179 \\
\hline \multirow[t]{2}{*}{1756} & $\begin{array}{l}3 \\
4\end{array}$ & $\begin{array}{l}25,000 \\
30,000\end{array}$ & & & $\begin{array}{l}2 \\
4\end{array}$ & $\begin{array}{l}+17,465 \\
-10,129\end{array}$ & & & \\
\hline & 5 & 12,000 & & & & & 1756 & 74,336 & 111,515 \\
\hline \multirow[t]{2}{*}{1757} & 6 & 84,963 & 2 & $+1,396$ & $\begin{array}{l}4 \\
6\end{array}$ & $\begin{array}{c}+10,129 \\
-3,480^{a}\end{array}$ & & & \\
\hline & & & & & 6 & $-7,255^{b}$ & 1757 & 85,753 & 197,268 \\
\hline \multirow[t]{2}{*}{1758} & 7 & 32,000 & & & 6 & $+3,209^{\mathrm{a}}$ & & & \\
\hline & 8 & 57,000 & & & $7-8$ & $-10,378^{\mathrm{b}}$ & 1758 & 81,831 & 279,099 \\
\hline \multirow[t]{3}{*}{1759} & 9 & 52,000 & & & 9 & $-2,378^{C}$ & & & \\
\hline & 10 & 10,000 & & & $\begin{array}{l}10 \\
6-8\end{array}$ & $\begin{array}{r}-457^{\mathrm{c}} \\
+10,483^{\mathrm{b}}\end{array}$ & & & \\
\hline & & & & & 6 & $+101^{\mathrm{a}}$ & 1759 & 69,749 & 348,848 \\
\hline \multirow[t]{4}{*}{1760} & 11 & 20,000 & & & 11 & $-914^{\mathrm{C}}$ & & & \\
\hline & 12 & 32,000 & & & 12 & $-1,463^{\mathrm{C}}$ & & & \\
\hline & & & & & 7- 8 & $+4,275^{\mathrm{b}}$ & & & \\
\hline & & & & & 6 & $+101^{\mathrm{a}}$ & 1760 & 53,999 & 402,847 \\
\hline \multirow[t]{2}{*}{1761} & & & & & $9-12$ & $+5,212^{C}$ & & & \\
\hline & & & & & 6 & $+32^{\mathrm{a}}$ & 1761 & 5,244 & 408,091 \\
\hline \multirow[t]{2}{*}{1762} & 13 & 30,000 & & & 13 & $-10,250$ & & & \\
\hline & & & & & 6 & $+32^{\mathrm{a}}$ & 1762 & 19,782 & 427,873 \\
\hline \multirow[t]{2}{*}{1763} & & & & & $\begin{array}{r}13 \\
8\end{array}$ & $\begin{array}{r}+10,250 \\
+375\end{array}$ & & & \\
\hline & & & & & 6 & $+2^{\mathrm{a}}$ & 1763 & 10,627 & 438,500 \\
\hline \multirow[t]{2}{*}{1764} & & & & & $7-8$ & $+2,500^{\mathrm{b}}$ & & & \\
\hline & & & & & 6 & $+2^{\mathrm{a}}$ & 1764 & 2,502 & 441,002 \\
\hline 1765 & & & & & & & 1765 & & 441,002 \\
\hline 1766 & & & & & & & 1766 & & 441,002 \\
\hline 1767 & & & & & & & 1767 & & 441,002 \\
\hline 1768 & & & & & & & 1768 & & 441,002 \\
\hline 1769 & 14 & 10,000 & & & & & 1769 & 10,000 & 451,002 \\
\hline 1770 & & & & & & & 1770 & & 451,002 \\
\hline 1771 & 15 & 30,000 & & & & & 1771 & 30,000 & 481,002 \\
\hline 1772 & & & & & & & 1772 & & 481,002 \\
\hline 1773 & & & & & & & 1773 & & 481,002 \\
\hline 1774 & & & & & & & 1774 & & 481,002 \\
\hline Total & & 484,963 & & $-3,960$ & & 0 & & 481,002 & \\
\hline
\end{tabular}

Sources: Table 2; Kennedy (1906a, pp. xi-xxv, 64-6, 108, 118-20, 124-8, 154-6, 283-5, 303; 1906b, pp. 72, 217-8; 1907, pp. 143, 171, 176-8, 356-7); McIlwaine (1908, pp. 15, 36-7, 115-6, 171-2, 249-50; 1909, pp. 388, 458, 48790); William and Marry College Quarterly Historical Magazine (1912, pp. 227-62).

Notes: See the text for construction. Em \# = paper money acts or emission numbers as listed in Table 2. $£_{\mathrm{VA}}=$ Virginia paper pounds at face value. Shillings and pence are rounded to the nearest pound. 
${ }^{\mathrm{a}}$ The 93,604£ $£_{\mathrm{VA}}$ notes from emissions \#2, \#3, and \#4 were not swapped for emission \#6 notes all at once, but over the next eight years. The net new emissions from this swap were the extra 6,359 $£_{\mathrm{VA}}$ emission \#6 notes printed to pay the 1.2 years of accrued interest on emission \#2, \#3, and \#4 notes. I assumed that this interest was only paid when the notes were brought in to be swapped. $6,359 \varepsilon_{\mathrm{VA}} / 93,604 \varepsilon_{\mathrm{VA}}=0.0679$. This percentage was used to convert notes listed as still held in the treasury to execute this swap into the net new emission \#6 notes that were emitted as the interest payment portion of this swap. I assume the $93,604 £_{\mathrm{VA}}$ total actually emitted for emissions \#2, \#3, and \#4 was known by the crafting of emission \#6, and it was known how many extra emission \#6 notes were needed to pay the accrued interest.

b $7,255 £_{\mathrm{VA}}$ of emission \#6 notes that were part of the new $80,000 £_{\mathrm{VA}}$ emission of emission \#6 notes were unspent in the treasury in 1758. This sum gets incorporated into discussions of emissions \#7 and \#8 that were still unspent in the treasury and when those unspent sums were no longer in the treasury and so must have been spent. $6,775 £_{\mathrm{VA}}$ of emissions \#7 and \#8 were designated to fund the Rangers (a military unit) and the Commissioner on Indian Affairs. This amount was reported as still held in the treasury for this purpose into 1760 , when $4,275 £_{\mathrm{VA}}$ was no longer mentioned as being so held. I assume that $3,275 £_{\mathrm{VA}}$ was released that year to fund the Rangers and $1,000 £_{\mathrm{VA}}$ to fund the Commissioner on Indian Affairs, as 2,500 $£_{\mathrm{VA}}$ was still reported as held in the treasury to fund the Commissioner on Indian Affairs in the years after 1761. This 2,500 $£_{\mathrm{VA}}$ shows up again in 1766 as part of the monies the treasurer, John Robinson, diverted out of the treasury as loans to his friends. Exactly what year this 2,500 $£_{\mathrm{VA}}$ was put into circulation by Robinson is unknown. It is arbitrarily placed in 1764 as a best guess.

c The $+5,212 £_{\mathrm{VA}}$ in 1761 from emissions \#9, \#10, \#11, and \#12 are pro-rated in subtraction across those emissions because which emission this added amount should be subtracted from was not indicated.

In other words, emission \#6 authorized 179,963£ $£_{\mathrm{VA}}$ notes which consisted of $80,000 £_{\mathrm{VA}}$ of new emissions plus $93,604 £_{\mathrm{VA}}$ in one-for-one currency swaps for notes outstanding from emissions \#2, \#3, and \#4 plus 6,359 $£_{\mathrm{VA}}$ in interest payments. The $1,396 £_{\mathrm{VA}}$ notes never emitted added to the $93,604 £_{\mathrm{VA}}$ notes actually emitted equals the $95,000 £_{\mathrm{VA}}$ originally authorized, which in turn when subtracted from the emission \#6 total authorization of $179,963 £_{\mathrm{VA}}$ equals $84,963 £_{\mathrm{VA}}$ net new emissions going into public hands.

The treasury accounts also list sums that were sitting in the treasury unspent from given emissions for some time after their initial authorization. Given that the treasury accounts never refer to these sums as being destroyed without being emitted, I assume that they were spent into public circulation at some later date. Column (3) in Table 3 lists these amounts as stated in the treasury accounts, subtracts these amounts from the amounts authorized in their respective emission year, and then adds these amounts back in the year where it seems reasonable to assume they were spent into public circulation.

For the most part, the numbers, along with the year when each is subtracted, are direct 
observations taken from the treasury accounts. The year when they are added back in, however, must be inferred as it is not directly stated in the treasury accounts. The method for placement assumes that following the last mention of a sum still sitting idle in the treasury, if that mention was early in the year, I assume that sum went into circulation in the last year it was mentioned. If the sum was last mentioned late in the year, then I assume it went into circulation in the following year. ${ }^{6}$ At this stage, the data construction process has moved from direct observations to controlled conjectures. Some potential error variance in the path of net new notes put into public circulation is introduced here.

Column (4) of Table 3 incorporates the two adjustments to the net new emissions authorized to produce the time-path of the net new emissions actually put into public circulation. Column (5) sums the accumulation of these emissions under the assumption that none were ever removed from circulation. It simply provides the maximum ceiling for total notes in circulation. Any analysis that leads to more than that listed in column (5) would not be credible.

\section{c. Removal of Notes from Public Circulation: Preliminary Evidence and Adjustments}

To derive the amount of notes in public circulation, notes removed from public circulation must be subtracted from the net new notes put into public circulation. Table 4 provides information on the amount of notes removed, and estimates of when they were removed, from public circulation. For the most part, the amounts of notes removed from public circulation are direct observations taken from the treasury accounts. When these notes were removed from public circulation prior to their reporting in the treasury accounts, however, must be estimated. Some back-projection, interpolation, data cloning, and other placement estimation methods are required. The methods used depend on the type of information provided in the

\footnotetext{
${ }^{6}$ Trying to prorate the introduction of these notes by month, say for some months at the end of a year and then some in the months after the New Year, was not attempted here. The spending by the treasury each month is unknown, and to guess at its prorated flow would be pure speculation.
} 
Table $4 \quad$ Net New Emissions Redeemed and Removed from Public Circulation, 1755-1775

\begin{tabular}{|c|c|c|c|c|c|c|c|}
\hline \multirow[b]{2}{*}{ Year } & \multicolumn{2}{|c|}{\begin{tabular}{l}
\multicolumn{1}{c}{$(1)$} \\
When Net New \\
Notes Redeemed \\
from the Public \\
were Reported \\
as Burned
\end{tabular}} & \multicolumn{2}{|c|}{$\begin{array}{l}\quad(2) \\
\text { When these } \\
\text { Notes were } \\
\text { Likely being } \\
\text { held for } \\
\text { Burning }\end{array}$} & $\begin{array}{l}\text { Prelin } \\
\text { Net } 1 \\
\text { Remo } \\
\text { Publi } \\
\text { Each }\end{array}$ & $\begin{array}{l}\text { ary Total: } \\
\text { Notes } \\
\text { form } \\
\text { irculation } \\
\text { ar }\end{array}$ & \multirow[t]{2}{*}{$\begin{array}{l}\qquad(4) \\
\text { Adjusted Total: } \\
\text { When these Notes } \\
\text { were Likely Removed } \\
\text { from Public Circulation } \\
£_{\mathrm{VA}}\end{array}$} \\
\hline & Em \# & $£_{\mathrm{VA}}$ & Em \# & $£_{\mathrm{VA}}$ & Year & $£_{\mathrm{VA}}$ & \\
\hline 1755 & & 0 & & 0 & 1755 & 0 & 0 \\
\hline 1756 & & 0 & 1 & $15,932^{\mathrm{a}}$ & 1756 & $15,932^{\mathrm{a}}$ & $15,932^{\mathrm{a}}$ \\
\hline 1757 & 1 & $15,932^{\mathrm{a}}$ & & 0 & 1757 & 0 & 13,731 \\
\hline 1758 & 5 & 5,518 & 5 & 5,518 & 1758 & 5,518 & 26,118 \\
\hline \multirow[t]{2}{*}{1759} & 5 & 1,891 & 5 & 1,891 & & & \\
\hline & & & $6 \& 7$ & 10,052 & 1759 & 11,943 & 26,118 \\
\hline 1760 & $6 \& 7$ & 30,731 & $6 \& 7$ & 30,313 & 1760 & 30,313 & 24,682 \\
\hline \multirow[t]{2}{*}{1761} & $6 \& 7$ & 20,426 & $6 \& 7$ & 17,614 & & & \\
\hline & 5 & 1,648 & 5 & 1,648 & 1761 & 19,262 & 28,003 \\
\hline \multirow[t]{3}{*}{1762} & $\begin{array}{c}6 \& 7 \\
5\end{array}$ & 23,244 & $\begin{array}{c}6 \& 7 \\
5\end{array}$ & 16,422 & & & \\
\hline & $\begin{array}{c}5 \\
8-13\end{array}$ & $\begin{array}{r}2,066 \\
11,256\end{array}$ & $\begin{array}{c}5 \\
8-13\end{array}$ & $\begin{array}{r}2,066 \\
11,256\end{array}$ & & & \\
\hline & & & --- & 49,875 & 1762 & 79,619 & 28,003 \\
\hline 1763 & --- & 49,875 & --- & 22,014 & 1763 & 22,014 & 22,793 \\
\hline 1764 & & $?$ & --- & 22,014 & 1764 & 22,014 & 26,300 \\
\hline 1765 & & ? & --- & 22,014 & 1765 & 22,014 & 16,949 \\
\hline 1766 & & $?$ & --- & 2,225 & 1766 & 2,225 & 19,148 \\
\hline 1767 & --- & 2,225 & --- & 41,765 & 1767 & 41,765 & 25,751 \\
\hline 1768 & --- & 41,765 & --- & 29,264 & 1768 & 29,264 & 25,751 \\
\hline 1769 & --- & 39,906 & --- & 18,442 & 1769 & 18,442 & 21,046 \\
\hline 1770 & --- & 7,800 & & & 1770 & 10,541 & 10,541 \\
\hline 1771 & & & & & 1771 & 10,944 & 10,944 \\
\hline 1772 & & & & & 1772 & 36,562 & 36,562 \\
\hline 1773 & & & & & 1773 & 36,562 & 36,562 \\
\hline 1774 & & & & & 1774 & 23,355 & 23,355 \\
\hline 1775 & & & & & 1775 & 2,763 & 2,763 \\
\hline Total & & & & & & 441,052 & 441,052 \\
\hline
\end{tabular}

Sources: See the sources listed for Table 3.

Notes: See the notes to Table 3 and the text for construction. After 1762, redemption accounts do not report which emissions were being burned.

${ }^{\mathrm{a}}$ Emission \#1 had 3,961 $£_{\mathrm{VA}}$ never emitted. Out of the 16,039 $£_{\mathrm{VA}}$ emitted, 15,932 $£_{\mathrm{VA}}$ were redeemed in 1756 and subsequently burned in 1757 . What happened to the difference, $107 £_{\mathrm{VA}}$, is unknown. I assume it was lost by the public - a one-year loss rate of 0.67 percent is not unthinkable. At redemption, 606 $£_{\mathrm{VA}}$ was paid in interest for the one year period that the emission was outstanding. I assume the interest payment was in specie or tobacco claims and not notes as no statement to the contrary was recorded.

treasury accounts. In addition, the treasury accounts do not use consist language when indicating that notes were removed and burned. Some liberties of interpretation are required. At this point, we have moved the farthest away from direct observation and thereby introduced the most 
potential error variance into the time path of notes in public circulation.

Column (1) of Table 4 reports the direct evidence from the treasury accounts at the time it was reported in the House of Burgesses of the amount of notes burned. Several subtle interpretations, however, must be used to make sense of this evidence. First, statements about total notes burned to date, such as on 7 April 1768, cannot be directly used because they refer to total notes printed and not notes in public circulation (Kennedy 1906a, p. 155). Burning notes taken in as one-for-one swaps for new notes has no effect on total notes in public circulation. These burnt notes are removed from column (1) totals.

Second, notes removed and burned from emission \#5 must be indirectly inferred. After 1757 , i.e. after emission \#5 was to be fully redeemed, the treasury accounts state the amount of funds remaining in a dedicated account to fully redeem emission \#5 notes as they were brought in for redemption. I assume that the difference between the amount of emission \#5 notes emitted, $12,000 £_{\mathrm{VA}}$, and the sum remaining in the treasury account for its redemption measures the amount of emission \#5 notes redeemed and burned to that date (see Table 8 below).

Column (2) of Table 4 makes several adjustments to the data in column (1). First, column (2) makes a placement adjustment. Again, the treasury accounts as reported in the Journals of the House of Burgesses were typically made early in the year and so refer to redemptions made in the prior year. Most redemption taxes were collected in the fall, and so notes reported in the Journals of the House of Burgesses as burned were likely removed via tax payments in the prior year. As such, the amounts stated in the treasury accounts of notes burned in the early part of the year are moved to the immediately prior year in terms of when they were removed from public circulation. The amounts stated in the treasury accounts of notes burned in the latter part of the year are assumed to have been removed from public circulation in that same year. 
Second, missing accounts for the years 1764 through 1766 are filled in via backprojection and interpolation. I assume that any time the treasury accounts mention a sum of notes burned in a given year, that that sum is the complete amount removed and burned that year. So only years when nothing is mentioned must have their amounts estimated. In the last three years of John Robinson’s tenure as treasurer (he had been treasurer since 1738 and died in 1766), little information was recorded from the treasury accounts.

The redemption amounts for these three years are back-projected and interpolated values based on the difference between redemptions up through 1762 estimated in column (2) of Table 4, and the 1768 treasury account of the total accumulated notes burned between 1755 and 1 April 1767. The treasury accounts report an accumulated total of 326,192 $£_{\mathrm{VA}}$ notes burned before 1 April 1767. This number is out of all notes printed, not all notes emitted into public circulation. Thus, it must be reduced by notes burned that were not net new emissions to the public. This reduction includes $3,960 £_{\mathrm{VA}}$ never spent out of treasury and the 93,604£ $£_{\mathrm{VA}}$ that were emission \#6 one-for-one currency swaps for emission \#2, \#3, and \#4 notes (the swapped notes being presumably burned, though no direct statements of such were made in the treasury accounts). The amount of notes redeemed from the public and burned up through 1762 is estimated in column (2) of Table 4 to be $162,587 £_{\mathrm{VA}}$. A statement of notes burned in 1767 that were from removals in 1766 exists, so only three years, 1763, 1764, and 1765, need to be filled by this estimate. The calculation is: 326,192 - 3,960 - 93,604 $-162,587=66,041 ; 66,041$ / $3=22,014$ for each of these years.

Two additional back-projected, prorated interpolation exercises are needed to finish constructing the data on note removals for the period after 1769. Column (3) of Table 4 reports the outcome of these exercises, along with the resulting preliminary reconstructed time path of 
net new notes removed from the public each year for 1755 into 1775 . The amounts of net new emissions removed in the years 1770 and 1771 are estimated as follows: The difference between the House of Burgesses treasury account of notes in circulation between 1768 and 1771 is $(127,714-88,190)=39,524 £_{\mathrm{VA}}$. The amount redeemed in 1769 is subtracted to yield $(39,524-$ $18,442)=21,082 £_{\mathrm{VA}}$ for redemptions in 1770 and 1771 . This number is prorated and because these are for "old" notes only, the amounts of "new" notes directly mentioned as redeemed in the treasury accounts for these years are added to those sums, i.e. $403 £_{\mathrm{VA}}$ for 1771.

The amounts of net new emissions removed in the years 1772 into 1775 are estimated as follows: The difference between the House of Burgesses treasury account of “old” notes in circulation between 1771 and 1772 is $(88,190-54,391)=33,799 £_{\mathrm{VA}}$. The implied redemption of

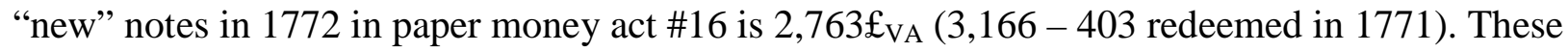
two numbers are added to get the total redeemed in 1772. I assume that the same amounts were redeemed in 1773 . The same amounts of "new" notes are assumed to be redeemed in 1774 and in 1775. The amount of “old” notes redeemed in 1774 is taken as the remainder of "old” notes after subtracting out their 1773 redemption, i.e. 54,391 - 33,799=20,592 $£_{\mathrm{VAA}}$. As such, no "old” notes remain in circulation after 1774, and only “new” notes remained in circulation after 1774.

Column (3) of Table 4 yields my preliminary estimate of note removals. Subtracting these numbers from net new emissions actually put into public circulation in column (4) of Table 3 yields my preliminary estimate of the amount of notes actually in public circulation as displayed in Figure 1. This preliminary estimate is close to what Brock reports. Thus, Brock must have done some redemption analysis adjustments along the lines done here in columns (1), (2), and (3) of Table 4, though perhaps not as thoroughly as done here. 


\section{d. Removal of Notes from Public Circulation: The Final Adjustment}

The estimate of notes removed from public circulation each year in column (3) of Table 4 assumes that notes removed via tax payments did not sit long in the treasury before being burned. Given that tax payment obligations were relatively constant, a relatively constant amount of notes should have been removed from public circulation each year. Yet, the numbers in column (3) of Table 4 show considerable yearly variation. In some years, the amount listed appears well in excess of that year's tax obligation. As such, notes redeemed from the public via tax payments must have sat idle in the treasury for some time before being burned. The language in the statutory paper money act for emission \#11 implies as much (Hening 1969, v. 7, p. 353). Thus, an additional placement adjustment is needed to account for when notes were likely removed from public circulation via tax payments.

The amount of revenue collected each year from taxes imposed by the paper money acts is not recorded in the primary sources. The paper money acts only state the type of taxes imposed, the tax rate per tax type, and the years over which each tax was in force. From 1755 through 1769, the taxes imposed by the paper money acts included a poll tax, a land tax, a slave import duty, and a tobacco export duty. Table 5 reports the tax rate per each of these tax types per year imposed when consolidated across all paper money acts.

In 1763, the treasury accounts report the revenue expected that year for each of these taxes (Kennedy 1907, p. 178). Using the expected revenues per tax type for 1763, given the tax rates listed in Table 5, the expected tax revenue per tax type for each year from 1755 through 1769 can be cloned. Table 5 provides these cloned expected tax revenues per tax type imposed by the paper money acts. The raw total across all tax types is reduced by a 7 percent yearly collection fee. This fee was imposed for the year 1763, and I assume it was the same for other 
Table 5 Consolidated Yearly Tax Rates and Expected Tax Revenues Imposed by the Paper Money Acts, 1755-1769

\begin{tabular}{rlrlllllll}
\hline \\
Year
\end{tabular}

Source: Hening (1969, v. 6, pp. 461-81, 521-30; v. 7, pp. 9-25, 26-33, 46-54, 69-87, 163-9, 171-9, 255-65, 331-7, 347-58, 357-63, 465-6, 493-502; v. 8, pp. 342-8, 493-503, 647-51); Kennedy (1907, p. 178).

Notes: See text for construction.

years. ${ }^{7}$ After 1769, poll and land taxes were removed and taxes on carriages and licenses were

added in the paper money acts. The expected revenues generated per tax rate cannot be cloned in post-1769 years, as was done for the pre-1770 years, because of a lack of similar information in the treasury accounts after 1769 .

The expected revenues listed in Table 5 are used to adjust the yearly placement of note removals listed in column (3) of Table 4. Note removals are spread or smoothed over time by weighting them by expected tax revenues in each year. ${ }^{8}$ This adjustment method is applied

\footnotetext{
${ }^{7}$ I made no effort to adjust expected tax revenues to changes in population, land ownership, and tobacco exports over time. The treasury accounts when estimating tax revenues made no such adjustments. In addition, the data on such changes are at best speculative, so no adjustments were attempted.

${ }^{8}$ I made no adjustment for tax arrears. Tax arrears mentioned in the treasury accounts were either minuscule or not mentioned at all before 1766. Substantial tax arrears were mentioned in the treasury accounts for the years 1766, 1768,1769 , and 1772, but not in the intervening years. As such, tax arrears do not appear to accumulate from year to year. The tax arrears mentioned in 1768, 1769, and 1772 are not larger than that year's expected tax revenues. Thus, I assume that tax arrears are mostly delayed transfers of taxes collected by sheriffs to the central treasury for the current year. These taxes are assumed to show up shortly after that year's treasury accounts were recorded in the Journals of the House of Burgesses. See the sources cited in Table 3.
} 
separately to three periods, 1757 through 1762, 1763 through 1765, and 1766 through 1769 . The three periods are chosen based on the structure of the surviving treasury accounts. In 1763, the treasury provided the most thorough accounting of any year, including some accumulative accounting from 1757 to present (Kennedy 1907, pp. 177-8). Between 1763 and 1766, little information about what was in the treasury accounts was recorded. In 1766, the treasury accounts revealed the extent of the John Robinson scandal in the immediately prior years at the treasury, and a new treasurer took over from 1766 through 1769 (Kennedy 1906a).

The placement adjustments are made as follows: Total notes burned from 1757 through 1762 in column (3) of Table 4 are divided by the total expected tax revenues from 1757 through 1762 in Table 5, namely $146,655 £_{\mathrm{VA}} / 189,953 £_{\mathrm{VA}}=0.77206$. Notes redeemed per year over these years are estimated by multiplying 0.77206 by the expected tax revenue in that year as listed in Table 5. Total notes burned from 1763 through 1765 in column (3) of Table 4 are divided by the total expected tax revenues from 1763 through 1765 in Table 5, namely $66,042 £_{\mathrm{VA}} / 105,090 £_{\mathrm{VA}}=0.62843$. Notes redeemed per year over these years are estimated by multiplying 0.62843 by the expected tax revenue in that year as listed in Table 5 . Total notes burned from 1766 through 1769 in column (3) of Table 4 are divided by the total expected tax revenues from 1766 through 1769 in Table 5, namely 91,696 $£_{\mathrm{VA}} / 129,154 £_{\mathrm{VA}}=0.70997$. Notes redeemed per year over these years are estimated by multiplying 0.70997 by the expected tax revenue in that year as listed in Table 5. The end result is reported in column (4) of Table 4.

The exercise above yields an implied division of tax payments into 77 percent being in notes in 1757 through 1762, 63 percent being in notes in 1763 through 1765, and 71 percent being in notes in 1766 through 1769, with the balance in each period being in specie or tobacco monies. This percentage division in what media was used to pay yearly taxes is consistent with, 
and so corroborated by, the treasury account statements in 1769 and 1770 about the note-tospecie division in tax payments (see below).

\section{e. The Resulting Time Path of Notes in Public Circulation}

Table 6 subtracts the estimated net new notes removed from the public from the estimated net new notes actually put into public circulation to get the time path of notes remaining in public circulation each year. These amounts are slightly different from the treasury account statements of the amounts in circulation, because the treasury account statements specifically refer only to "old” notes in circulation, and because the treasury account statements calculate notes in circulation by taking total notes ever printed and subtracting total notes ever burned. To the extent that notes sitting idle in the treasury, never emitted or not yet burned, are included in this construction, the treasury accounts misstate the amounts in public circulation.

Alternative assumptions, back-projects, and interpolations are certainly possible, and so alternative estimates of the amount of notes in public circulation could be plausible. However, any deviation from that done here would either cause the coherent fabric of the forensically consistent and interlocking patterns to unravel or require less plausible assumptions. While error variance exists in these estimates, it is relatively small given the limited range of plausible alternative assumption and estimation methods that maintain an overall forensic coherence.

\section{Denominational Structure}

Were Virginia’s notes used as a circulating medium of exchange? The denominational structure is consistent with such usage. Virginia's notes were issued in relatively small denominations, small enough to make paying yearly tax assessments easy with said notes, and small enough to make it an easy domestic circulating medium of exchange in terms of being able to make change with said notes. For emissions \#6, \#8, \#9, \#11, \#12, and \#13 the denominational 
Table 6 Virginia Notes in Public Circulation, 1755-1775

\begin{tabular}{|c|c|c|c|c|}
\hline Year & \begin{tabular}{l}
\multicolumn{1}{c}{$(1)$} \\
Net New Emissions \\
Actually Put into \\
Public Circulation \\
$\qquad £_{\mathrm{VA}}$
\end{tabular} & $\begin{array}{c}(2) \\
\text { Net New Notes } \\
\text { Removed from } \\
\text { the Public } \\
\varepsilon_{\mathrm{VA}}\end{array}$ & $\begin{array}{l}\text { (3) } \\
\text { Resulting Notes in } \\
\text { Public Circulation } \\
£_{\mathrm{VA}}\end{array}$ & $\begin{array}{c}\text { (4) } \\
\text { From House of Burgesses } \\
\text { and Treasurer Statements } \\
\text { of Notes in Circulation } \\
\varepsilon_{\mathrm{VA}}\end{array}$ \\
\hline 1755 & 37,179 & 0 & 37,179 & \\
\hline 1756 & 74,336 & 15,932 & 95,582 & \\
\hline 1757 & 85,753 & 13,731 & 167,605 & \\
\hline 1758 & 81,831 & 26,118 & 223,318 & \\
\hline 1759 & 69,749 & 26,118 & 266,949 & \\
\hline 1760 & 53,999 & 24,682 & 296,266 & \\
\hline 1761 & 5,244 & 28,003 & 273,507 & \\
\hline 1762 & 19,782 & 28,003 & 265,286 & \\
\hline 1763 & 10,627 & 22,793 & 253,120 & \\
\hline 1764 & 2,502 & 26,300 & 229,322 & \\
\hline 1765 & 0 & 16,949 & 212,373 & \\
\hline 1766 & 0 & 19,148 & 193,225 & 206,727 \\
\hline 1767 & 0 & 25,751 & 167,474 & 170,420 \\
\hline 1768 & 0 & 25,751 & 141,723 & 127,714 \\
\hline 1769 & 10,000 & 21,046 & 130,677 & \\
\hline 1770 & 0 & 10,541 & 120,136 & \\
\hline 1771 & 30,000 & 10,944 & 139,192 & 88,190 \\
\hline 1772 & 0 & 36,562 & 102,630 & 54,391 \\
\hline 1773 & 0 & 36,562 & 66,068 & \\
\hline 1774 & 0 & 23,355 & 42,713 & \\
\hline 1775 & 0 & 2,763 & 39,950 & \\
\hline Totals & 481,002 & 441,052 & & \\
\hline
\end{tabular}

Sources: Tables 3 and 4 ; for primary sources see the source notes to Tables 2 and 3.

Notes: See the notes to Table 3. Column (1) is from Table 3 column (4). Column (2) is from Table 4 column (4).

Resulting Notes in Public Circulation takes the number in column (3) in year $t$ and adds the number in column (1) in year $t+1$ and then subtracts the number in column (2) in year $t+1$ to get the number in column (3) for year $t+1.1775$ does not include new emissions made later in that year (Newman 2008, pp. 444-6).

${ }^{\mathrm{a}}$ These are statements about the amount of notes in circulation in the treasury accounts as reported in the Journal of the House of Burgesses or by the treasurer Robert Carter Nicholas in letters. These statements explicitly refer only to "old" note, i.e. those emitted before 1769, and not to "new" notes, i.e. those emitted after 1768 . These statements were also made early in the year and relied on information on notes burned that were received in taxes from late in the previous year. Thus, the year for these numbers is moved one forward from when reported to reflect when notes were actually taxed out of circulation, rather than when they were subsequently burned.

structure was fixed by the assembly in each emission's respective paper money act. These emissions represent 77 percent of the total net new notes emitted. Table 7 shows the denominational structure in terms of the percentage of units and the percentage of value authorized for each denomination per emission and for the total for all emissions reported. In addition, Table 7 reports the face value of each denomination of Virginia's paper money in 


\begin{tabular}{|c|c|c|c|c|c|c|c|c|c|c|c|c|c|c|c|c|c|}
\hline \multirow{2}{*}{$\begin{array}{l}\text { Virginia } \\
\text { Notes } \\
\text { Issued } \\
£_{\mathrm{VA}}\end{array}$} & \multirow{2}{*}{$\begin{array}{c}\text { Face } \\
\text { Value in } \\
£_{S}\end{array}$} & \multirow{2}{*}{$\begin{array}{l}\text { Face Value } \\
\text { in Spanish } \\
\text { Silver } \\
\text { Dollars }\end{array}$} & \multirow{2}{*}{$\begin{array}{l}\text { Approximate } \\
\text { Value in } \\
2012 \text { U.S. } \\
\text { Dollars }^{\mathrm{a}}\end{array}$} & \multicolumn{2}{|c|}{$\begin{array}{l}\text { e Emission } \\
\# 6: 1757\end{array}$} & \multicolumn{2}{|c|}{$\begin{array}{l}\text { Emission } \\
\text { \#8: } 1758\end{array}$} & \multicolumn{2}{|c|}{$\begin{array}{l}\text { Emission } \\
\# 9: 1759\end{array}$} & \multicolumn{2}{|c|}{$\begin{array}{l}\text { Emission } \\
\# 11: 1760\end{array}$} & \multicolumn{2}{|c|}{$\begin{array}{l}\text { Emission } \\
\# 12: 1760\end{array}$} & \multicolumn{2}{|c|}{$\begin{array}{l}\text { Emission } \\
\# 13: 1762\end{array}$} & \multicolumn{2}{|c|}{$\begin{array}{c}\text { Totals }^{\mathrm{c}} \\
1757-1762\end{array}$} \\
\hline & & & & $\begin{array}{l}\text { Units } \\
\%\end{array}$ & $\begin{array}{l}\text { Value } \\
\%\end{array}$ & $\begin{array}{c}\text { Units } \\
\%\end{array}$ & $\begin{array}{c}\text { Value }^{\mathrm{b}} \\
\%\end{array}$ & $\begin{array}{l}\text { Units } \\
\%\end{array}$ & $\begin{array}{l}\text { Value } \\
\%\end{array}$ & $\begin{array}{l}\text { Units } \\
\%\end{array}$ & $\begin{array}{l}\text { Value } \\
\%\end{array}$ & $\begin{array}{c}\text { Units } \\
\%\end{array}$ & $\begin{array}{c}\text { Value } \\
\%\end{array}$ & $\begin{array}{l}\text { Units } \\
\%\end{array}$ & $\begin{array}{l}\text { Value } \\
\%\end{array}$ & $\begin{array}{l}\text { Units } \\
\%\end{array}$ & $\begin{array}{c}\text { Value } \\
\%\end{array}$ \\
\hline 0.0500 & 0.04 & 0.1739 & 5.39 & 15.7 & 0.9 & 15.8 & 1.8 & 15.9 & 1.7 & & & 25.1 & 2.6 & & & 15.6 & 1.2 \\
\hline 0.0625 & 0.05 & 0.2174 & 6.74 & 15.7 & 1.1 & 15.8 & 2.2 & 15.9 & 2.1 & $\ldots$ & $\ldots$ & 25.1 & 3.3 & $\ldots$ & $\ldots$ & 15.6 & 1.5 \\
\hline 0.1250 & 0.10 & 0.4348 & 13.48 & 14.3 & 2.1 & 19.7 & 5.5 & 17.9 & 4.8 & 33.2 & 3.3 & 10.5 & 2.7 & 22.5 & 2.8 & 16.8 & 3.2 \\
\hline 0.2500 & 0.20 & 0.8696 & 26.96 & 14.3 & 4.2 & 19.7 & 11.0 & 17.9 & 9.6 & 33.2 & 6.7 & 10.5 & 5.5 & 22.9 & 5.6 & 16.8 & 6.3 \\
\hline 0.5000 & 0.40 & 1.7391 & 53.91 & 14.3 & 8.3 & 11.8 & 13.2 & 13.4 & 14.4 & $\ldots$ & $\ldots$ & 10.5 & 10.9 & 17.1 & 8.3 & 12.9 & 9.7 \\
\hline 1.0000 & 0.80 & 3.4783 & 107.83 & 14.3 & 16.7 & 11.8 & 26.5 & 13.4 & 28.8 & $\ldots$ & $\ldots$ & 10.5 & 21.9 & 17.1 & 16.7 & 12.9 & 19.4 \\
\hline 2.0000 & 1.60 & 6.9565 & 215.65 & 2.9 & 6.7 & 1.8 & 7.9 & 1.8 & 7.7 & 11.2 & 18.0 & 2.6 & 10.6 & 6.8 & 13.3 & 2.8 & 8.5 \\
\hline 3.0000 & 2.40 & 10.4348 & 323.48 & 2.9 & 10.0 & 1.8 & 11.9 & 1.8 & 11.5 & 11.2 & 27.0 & 2.6 & 15.9 & 6.8 & 20.0 & 2.8 & 12.8 \\
\hline 5.0000 & 4.00 & 17.3913 & 539.13 & 2.9 & 16.7 & 1.8 & 19.9 & 1.8 & 19.2 & 11.2 & 45.0 & 2.6 & 26.6 & 6.8 & 33.3 & 2.8 & 21.3 \\
\hline 10.0000 & 8.00 & 34.7876 & $1,078.42$ & 2.9 & 33.3 & $\ldots$ & $\ldots$ & $\ldots$ & $\ldots$ & $\ldots$ & $\ldots$ & $\ldots$ & $\ldots$ & $\ldots$ & $\ldots$ & 1.1 & 16.2 \\
\hline & & & & $100 \%$ & $100 \%$ & $00 \%$ & $100 \%$ & $\overline{100 \%}$ & $100 \%$ & $\overline{100 \%}$ & $100 \%$ & $\overline{100 \%}$ & $100 \%$ & $\overline{100 \%}$ & $100 \%$ & $100 \%$ & $100 \%$ \\
\hline
\end{tabular}

Sources: Table 2; Hening (1969, v. 7, pp. 82-3, 175, 259-60, 350, 360-1, 498); McCusker (1978, p. 10).

a From http://eh.net "measuring worth—relative value of U.S. Dollars" using the 1775 to 2012 CPI conversion algorithm.

$\mathrm{b}$ The units multiplied by the value only sum to $56,625 £_{\mathrm{VA}}$ and not the $57,000 £_{\mathrm{VA}}$ authorized for this emission. Whether and how this discrepancy was accommodated is currently unknown.

${ }^{\mathrm{c}}$ Total units are 560,107 and the total value is $370,588 £_{\mathrm{VA}}$ in the data covered. 
pounds sterling, Spanish silver dollars, and 2012 U.S. dollars equivalents.

Comparing Table 7 with the yearly tax burdens imposed in Table 5 indicates that well over 50 percent of the units emitted were in a denomination small enough to pay an individual's yearly taxes without the necessity of resorting to tobacco or specie monies to make change to complete that year's tax payment. Table 7 also is consistent with John Hanson II's (1979, 1980a, 1980b) argument that the colonies intentionally issued paper money in small denominations to facilitate the making of change in local transactions. Hanson (1979, p. 284), however, only reports the denominational structure of Virginia's paper money using data from 1759 . He also lists no source for this data. Hanson (1980a, p. 414; 1980b, p. 171) dropped Virginia data from his analysis. Why is unknown. Table 7 is certainly consistent with the denominational structure Hanson reports for the other colonies.

\section{How the Redemption Process Worked}

Every paper money act included additional new taxes, typically a land tax and a poll tax, that were operative for a number of years. The number of years over which these new additional taxes were operative was chosen so as to generate enough funds to fully redeem the notes authorized by each respective paper money act. The date in each paper money act set for the final redemption of the notes authorized by that act closely matched the end to the taxing period set by that act. The final legislated redemption date for each emission is listed in Table 2.

The Virginia legislature took note redemption and its effect on controlling the value of its paper money seriously. Such is illustrated in the March 1760 paper money act which stated,

And whereas it is of the greatest importance to preserve the credit of the paper currency of this colony, and nothing can contribute more to that end than a due care to satisfy the publick that the paper bills of credit, or treasury-notes, are properly sunk, according to the true intent and meaning of the several acts of assembly passed for emitting the same; and the establishing a regular method for this purpose may prevent difficulties and confusion in settling the publick accounts,... Be it therefore enacted, by 
the authority aforesaid, That Peyton Randolph, esquire, Robert Carter Nicholas, Benjamin Waller, Lewis Burwell and George Wythe, gentleman, or any three of them, be, and they are hereby appointed a committee, to examine at least twice in every year (and oftener, if thereto desired by the treasurer for the time being) all such bills of credit, or treasury-notes, redeemable on the first day of March, one thousand seven hundred and sixty five, as have been or shall be paid into the treasury, in discharge of the duties and taxes imposed by any former act of assembly; and upon receipt of the said bills or notes, the said committee shall give to the treasurer for the time being a certificate of the amount thereof, which shall avail the said treasurer in the settlements of his accounts as effectually, at all intents and purposes, as if he produced the said bills or notes themselves: And the said committee are hereby required and directed, so soon as they have given such certificate, to cause all such bills or notes to be burnt and destroyed. (Hening 1969, v. 7, p. 353, italics in the original)

If the taxes accompanying a paper money act were paid in that act's notes then the amount of the notes from that emission in circulation would decline at a more or less constant rate from its initial emission year to its final legislated redemption year. If these taxes were paid by other means, such as in tobacco or specie coins, then the notes would continue in circulation until the final legislated redemption year when they could be redeemed at face value and removed from circulation using the accumulated tax receipts in the treasury. The language in the 1756 paper money acts illustrates this redemption structure.

That all such notes, so issued, shall be redeemable on the last day of June one thousand seven hundred and sixty, and shall then be paid by the treasurer... That the several sums of money and tobacco to be collected, by virtue of this act,... shall be,...paid to John Robinson, esquire, treasurer of this colony,... That the money to be raised by the duties imposed by this act, shall stand, be, and remain as a security for the redemption of the said treasurer notes so to be issued, and the said John Robinson, treasurer,... is hereby required to apply all such money, as shall come to his hands, by virtue of this act, for, and toward the redemption of such treasury notes, and to no other use or purpose whatsoever. (Hening 1969, v. 7, pp. 19, 29, 32).

All of Virginia's paper money acts had this language. By “money”, colonists typically meant specie monies, sometimes referred to as real money. The face value of the notes for redemption purposes was fixed in law to be $1 £_{\mathrm{VA}}=200$ pounds of tobacco $=1.25 £_{\mathrm{S}}$ [ $£_{\mathrm{VA}}=$ Virginia paper pounds, $£_{S}=$ pounds sterling] (Hening 1969, v. 6, pp. 468-9, 568-9; v. 7, pp. 9-10, 28-9). 
Were redemption taxes paid in notes or in specie? The treasury accounts provide some evidence to answer this question. The clearest statement in the treasury accounts was made on 15 June 1770 (Kennedy 1906b, p. 72, italics in the original).

It appears to your Committee, that the Balance in the Treasurer's Hands of Cash received of the several Collectors for Taxes appropriated to the Redemption of the old Treasury Notes [those issued before 1769], amount to Ten Thousand Three Hundred and Twenty-six Pounds Eleven Shillings, of which they have burnt and destroyed Seven Thousand Eight hundred Pounds, and have left in the Treasury, on that Account, in Specie, a Balance of Two Thousand Five Hundred and Twenty-six Pounds Eleven Shillings to be exchanged for old Treasury Notes.

A redemption tax of $10,327 £_{\mathrm{VA}}$ was collected, of which $2,527 £_{\mathrm{VA}}$ was in specie that was explicitly set aside in a dedicated account to be used to redeem notes brought to the treasury. The rest of the tax payments were burnt, implying that those tax payments were made in notes. Therefore, 76 percent of this tax was paid in notes, and 24 percent was paid in specie.

The above statement sets an interpretative standard for similar statements in the treasury accounts that are not as direct. In particular, redemption taxes received that were burnt must have been paid in notes, and redemption taxes received but not burnt must have been paid in specie. These tax sums in specie must have been held in a separate account and earmarked to redeem notes brought to the treasury that had reached their final legislated redemption date.

Applying this interpretative standard indicates that of the $12,642 £_{\mathrm{VA}}$ redemption taxes received on 30 November 1769, 10,642 $\varepsilon_{\mathrm{VA}}$ were paid in notes that were burned, leaving $2,000 £_{\text {VA }}$ paid in specie (Kennedy 1906a, p. 303). Therefore, 84 percent of this tax was paid in notes, and 16 percent was paid in specie. The treasury account of 23 November 1769, regarding the prior year, indicates that of the $42,067 £_{\mathrm{VA}}$ redemption taxes collected, $29,264 £_{\mathrm{VA}}$ were paid in notes that were burned, leaving 12,800 $£_{\mathrm{VA}}$ paid in specie (Kennedy 1906a, p. 284). Therefore, 70 percent of this tax was paid in notes, and 30 percent was paid in specie. 
The above analysis establishes that redemption taxes generated specie sums that were to be held in the treasury until the final redemption date legislated for each paper money act, at which time holders of those notes could cash them in at face value for the specie held in the treasury for that purpose. However, at the final redemption date holders of the respective notes did not rush to the treasury to exchange them for specie. The notes continued in circulation and note holders could cash them in at the treasury at their leisure. Robert Nicholas Carter, Virginia treasurer after 1766, noted this behavior, "Most of the Merchants as well as others, ... preferred them [Virginia's treasury notes] either to Gold or Silver, as being more convenient for transacting the internal Business of the Country.” (William and Mary College Quarterly Historical Magazine 1912, p. 235)

Table 8 illustrates this behavior for emission \#5, the only emission that is uniquely specified throughout the treasury accounts. While the taxes to redeem all of emission \#5 appear to have been fully paid at the end of 1757 as legislatively required, 54 percent of that payment was in specie or tobacco monies. That sum sat in the treasury in a dedicated account and was used to redeem emission \#5 notes brought into the treasury slowly over the next nine years. What happened to the last remaining $305 £_{\mathrm{VA}}$ in specie or tobacco monies in this account after 1766 is unknown. The treasury accounts speculate that the public likely lost some notes, thus accounting for the lack of full redemption. A note loss rate of 2.5 percent would not be unthinkable. The total amount of notes of emission \#5 redeemed by 1766 was $11,695 £_{\mathrm{VA}}$ which corroborates that emission \#5 was for $12,000 £_{\mathrm{VA}}$ rather than for $10,000 £_{\mathrm{VA}}$ as stated by statutory law, see Table 2 .

Table 8, last column, provides an estimate of the amounts of specie (or tobacco monies) accumulated in the treasury over time. These were sums to be used to redeem notes at their final legislated redemption date. The estimated notes paid in as taxes each year in column (4) of Table 


\begin{tabular}{|c|c|c|c|}
\hline Year & $\begin{array}{l}\text { Tax Funds Reported } \\
\text { in the Treasury for } \\
\text { Redeeming Emission } \\
\text { \#5 Notes Still Out }\end{array}$ & $\begin{array}{l}\text { Implied Emission } \\
\text { \#5 Notes } \\
\text { Redeemed and } \\
\text { Burnt Each Year }\end{array}$ & $\begin{array}{l}\text { Estimated Accumulation of Non-Note Tax } \\
\text { Redemption Revenues in the Treasury } \\
\text { Earmarked to Redeem Notes at their Final } \\
\text { Respective Legislated Redemption Dates }\end{array}$ \\
\hline & $\varepsilon_{\mathrm{VA}}$ & $\varepsilon_{\mathrm{VA}}$ & $\varepsilon_{\mathrm{VA}}$ \\
\hline 1755 & & & 1,860 \\
\hline 1756 & & & 8,688 \\
\hline 1757 & & & 12,742 \\
\hline 1758 & 6,482 & 5,518 & 20,453 \\
\hline 1759 & 4,590 & 1,892 & 28,164 \\
\hline 1760 & & & 35,451 \\
\hline 1761 & 2,942 & 1,648 & 43,718 \\
\hline 1762 & 876 & 2,066 & 51,985 \\
\hline 1763 & & & 65,462 \\
\hline 1764 & & & 81,012 \\
\hline 1765 & 412 & 464 & 91,033 \\
\hline 1766 & 305 & 107 & 98,855 \\
\hline 1767 & & & 10,519 \\
\hline 1768 & & & 21,038 \\
\hline 1769 & & & 29,636 \\
\hline 1770 & & & 8,561 \\
\hline 1771 & & & 16,712 \\
\hline 1772 & & & 7,366 \\
\hline 1773 & & & 5,554 \\
\hline 1774 & & & 3,742 \\
\hline 1775 & & & 1,930 \\
\hline Totals & & 11,695 & \\
\hline
\end{tabular}

Source: See the sources in Table 2 and 3; Kennedy (1906a, pp. xi-xxv, 64-6, 108, 118-20, 124-8, 154-6, 283-5, 303; 1906b, pp. 72, 217-8; 1907, pp. 143, 171, 176-8, 356-7); McIlwaine (1908, pp. 15, 36-7, 115-6, 171-2, 249-50; 1909, pp. 388, 458, 487-90); William and Marry College Quarterly Historical Magazine (1912, pp. 227-62). Notes: See the text for construction.

4 are subtracted from the expected net tax revenues collected each year in Table 5 to get the amount of specie and tobacco monies paid into the treasury each year. These amounts accumulated in the treasury from year to year to 1766 .

The numbers for 1767 through 1772 are taken from the treasury accounts for these years. They were stated as the sums remaining on hand. They are assumed to be what is on hand for 
potential current note redemption. Therefore, these numbers are not added or accumulated from year to year. When stated early in the year, they are placed in the prior year to reflect when the action was actually executed.

The numbers for 1773 into 1775 are projected estimates based on the last treasury account from 1772. The estimate takes the taxes received for "old" notes in 1772, adjusted for a downward trend from 1769, and adds to that the taxes received for "new" notes. I assume the specie portion of these taxes was 20 percent. Thus, the total tax number is multiplied by 0.2 to get the specie funds available in the treasury for note redemption. These numbers are not added or accumulated over time as I assume that these sums were being used to redeem notes. This assumption is consistent with the fact that more notes were being redeemed and burned in these years than there were notes paid in as taxes. This estimate of the specie (or tobacco) monies accumulating in the treasury, which were to be used for future note redemption, provides an important correction to the history of the John Robinson treasury scandal.

\section{Reassessing the John Robinson Scandal}

John Robinson was the speaker of the House of Burgesses and treasurer of the colony from 1738 until his death 11 May 1766. The last years of his administration involved a financial scandal that occupied Virginia's political and legal system for a half decade. It led to the separation of the office of speaker of the House of Burgesses from the office of treasurer. The scandal involved the diversion of funds out of the treasury, without direct authorization from the legislature, into loans to Robinson’s friends. The accounting made on 12 December 1766 indicates that Robinson diverted out of the treasury $95,828 £_{\mathrm{VA}}$ in accumulated taxes received that were earmarked to redeem notes, 2,500 $£_{\mathrm{VA}}$ in notes in a fund reserved for the Commissioner on Indian Affairs, and 3,389 $£_{\mathrm{VA}}$ "on the public account”, for a total of 101,717£ $£_{\mathrm{VA}}$ (Ernst 1973, pp. 
174-96; Kennedy 1906a, pp. x-xxvi, 64-6; Mays 1952, pp. 174-208; Mays 1967, pp. 24-74).

Were the funds diverted notes or specie? Scholars have typically assumed these diverted funds were notes put back in circulation (Ernst 1973, pp. 188-96; Kennedy 1906a, p. x; Lee 1825, p. 22; Mays 1952, pp. 185-6). As such, this diversion could affect the amount of notes in circulation, and thus note depreciation. This claim, however, turns out to be presumption based on questionable logic. For example, Mays (1952, pp. 185-6) assumes that the diverted funds were notes because he assumes there was no specie in the colony. Therefore, all taxes must have been paid in notes. As shown above, the treasury accounts indicate that 16 to 30 percent of noteredemption taxes were paid in specie. As such, a considerable accumulation of specie funds in the treasury earmarked for future note redemption must have been occurring before 1766.

Ernst (1973, pp. 188-9) quotes Robert Carter Nicholas, the incoming treasurer after Robinson and an ardent anti-paper proponent, regarding the fund-diversion crisis that money "squeezed from the people for their taxes instead of being sunk at our Treasury as it ought to have been, was thrown back into circulation.” Even in this quote, it is unclear whether Nicholas means notes or specie being thrown back into circulation—-though Ernst assumes it meant notes. Ernst points out that Nicholas's conclusion was a deduction, not an observation. Nicholas reasoned that the only thing that could cause the exchange rate to deteriorate was too much paper money in circulation. Therefore, the diverted funds must have been notes put back in circulation. Ernst (1973, p. 189) concluded that “In Nicholas's mind at least the theory of money had plainly triumphed over reality,...” The exchange rate could have deteriorated just as easily due to the prospect of the non-redemption of notes due to the division of specie funds earmarked for note redemption out of the treasury. Yet, Ernst (1973, pp. 193-5) seems to accept that the diverted funds were notes even though he cannot square that conclusion with his finding that the notes in 
circulation were not expanding, but were instead sharply contracting at that time.

No direct evidence from the period exists stating that these diverted funds were notes, except for the $2,500 £_{\mathrm{VA}}$ in notes in a fund reserved for the Commissioner on Indian Affairs. A close reading of the primary sources and the secondary sources indicates that no one ever really says in what money the diverted funds were denominated. Ernst (1973, pp. 174-96) never quite commits to or directly says in what money the diverted funds were denominated, though a less than careful reading could induce a leap to the conclusion that it was notes. In the letters of Edmund Pendleton, the executor of John Robinson's estate, no mention is ever made that the diverted funds were notes (Mays 1967). In the treasury accounts no mention is made in what money the diverted funds were denominated. In the primary evidence offered by Kennedy (1906a, pp. X-xxvi) no mention is made in what money the diverted funds were denominated. The only direct statement that the diverted funds were notes, that I could find, is in the Memoir of the Life of Richard Henry Lee (Lee 1825, p. 22), “...he [John Robinson] had been induced to lend to many members of the House of Burgesses, the government bills which had been redeemed, and ought to have been destroyed.” This statement was written in 1825 by Richard Henry Lee’s grandson. It is not a memoir penned by Richard Henry Lee himself, nor is the above statement in the memoir ascribed to anyone. Its source is unknown. The hypothesis that it is just a long-after-the-fact supposition by a grandson cannot be rejected.

The last meaningful treasury account in the Journals of the House of Burgesses before Robinson’s death was in May of 1763. It is fairly comprehensive (Kennedy 1907, pp. 177-8). The treasury account of May 1763 indicates that sizable amounts of notes from emissions \#6 through \#12 were being paid in taxes and were burned in each year from 1760 into early 1763 (Kennedy 1907, pp. 177-8; Table 4). The treasury account was silent on the specie portion of the 
taxes collected — both on how much had accumulated and where it was. Notes received in tax payments before their end maturity were being burned, and in significant amounts. It is information on the specie portion of the tax payments that is missing.

The next treasury report, the last before Robinson’s death, was in May of 1765. It is relatively sketchy. That report lists $47,418 £_{\mathrm{VA}}$ on hand in the treasury for note redemption (Kennedy 1907, p. 356). Table 8 indicates that at least $81,012 £_{\mathrm{VA}}$ should have accumulated in the treasury by the start of 1765 for that purpose. The estimation procedure here, therefore, is consistent with at least $33,594 £_{\mathrm{VA}}$ having already been diverted out of the treasury by Robinson by early 1765.

The estimated specie portion of the accumulated taxes in the treasury from taxes imposed by the paper money acts into 1766 were $98,828 £_{\mathrm{VA}}$, see Table 8 . By early 1766 , Robinson had removed from the treasury $95,828 £_{\mathrm{VA}}$ of accumulated taxes held for redemption of notes when said notes' circulation time was at an end, see Table 2. In 1766, it was recorded that only $2,218 £_{\mathrm{VA}}$ was left in the treasury to pass on to the new treasurer after Robinson death (a sum to be used to redeem notes, thus this amount is assumed to be specie as notes could not redeem notes). The closeness of the $95,828 £_{\mathrm{VA}}$ figure with what would have accumulated in the treasury into 1766 , namely $\left(98,855 £_{\mathrm{VA}}-2,218 £_{\mathrm{VA}}\right)=96,637 £_{\mathrm{VA}}$, provides consistency for this interpretation. This consistency also indicates that the error variances in my data estimation procedures are small across the totality of the forensic data reconstruction project here.

Finally, a fund diversion of $95,828 £_{\mathrm{VA}}$ in notes cannot be made consistent with any of the statements in the later treasury accounts, those made after Robinson's death, regarding total notes in circulation. The only way they could be made consistent would be if there existed an unprecedented, massive, un-documented, and uncommented on redemption of notes in the early 
to mid-1760s in excess of that already mentioned in the treasury accounts. This inconsistency, in a forensic accounting sense, implies that the funds diverted were unlikely to be notes. Lastly, both Brock (1992, p. 116) and Ernst (1972, p. 370) must have implicitly or unknowingly assumed that the diverted funds were specie and not notes. The forensic accounting reconstruction of how they derived the amount of notes in circulation cannot yield their outcomes unless the assumption is made that the diverted funds were not notes.

\section{Conclusion}

I provide major improvements in the quantitative data on colonial Virginia’s paper money regime. These improved data will assist scholars in crafting their political, social, and economic narratives of the period, as well as assist economists in testing models of colonial paper money performance. I thoroughly explicate how these quantitative data are created, providing a methodological guide to understanding their soundness and fragility. If my data are rejected, then the data on colonial Virginia paper money currently in use (taken from the Historical Statistics) must also be rejected, for their construction is similar, if not as thorough, as that shown here for my data. Scholars of colonial America should know how colonial quantitative data are created. It should not remain a mystery. 


\section{References}

Brock, L. V. 1975. The Currency of the American Colonies, 1700-1764. New York: Arno.

Brock, L. V. 1992. The colonial currency, prices, and exchange rates. Essays in History 34, 70-132 [posthumously published].

Carter, S. B., et al. (eds.) 2006. Historical Statistics of the United States Earliest Times to the Present Millennial Edition, Volume 5. New York: Cambridge University Press.

Crumbley, D. L., Heitger, L. E., and Smith, G. S. 2013. Forensic and Investigative Accounting. Chicago: Wolters Kluwer, $6^{\text {th }}$ edn.

Davis, A. M. 1964. Colonial Currency Reprints, 1682-1751, Vols. 3-4. New York: Augustus M. Kelly.

Ernst, J. E. 1973. Money and Politics in America, 1755-1775. Chapel Hill, NC: University of North Carolina Press.

Greene, J. P. and Jellison, R. M. 1961. 'The currency act of 1764 in imperial-colonial relations, 1764-1776. The William and Mary Quarterly 18, 485-518.

Grubb, F. 2016. Is paper money just paper money? Experimentation and variation in the paper monies issued by the American colonies from 1690 to 1775. Research in Economic History, forthcoming.

Hammond, B. 1991. Banks and Politics in America. Princeton, NJ: Princeton University Press [original 1957].

Hanson, J. R. II. 1979. Money in the colonial American economy: an extension. Economic Inquiry 17, 281-286.

Hanson, J. R. II. 1980a. Small notes in the American colonies. Explorations in Economic History $17,411-420$.

Hanson, J. R. II. 1980b. The economic development of the thirteen continental colonies, 1720 to 1775: a critique. William and Mary Quarterly 37, 165-175.

Hening, W. W. (ed.) 1969. The Statutes at Large; being a Collection of all the Laws of Virginia from the First Session of the Legislature, in the Year 1619, Vols. 6-9. Charlottesville, VA: University Press of Virginia [original: Richmond, VA: Franklin Press, 1819-1821].

Journal of the Commissioners for Trade and Plantations from January 1759 to December 1763: Preserved in the Public Records Office. 1970. Nendeln, Liechtenstein: Kraus-Thomson (original: 1935. London: Her Britannic Majesty’s Stationery Office). 
Kennedy, J. P. (ed.) 1905 Journals of the House of Burgesses of Virginia, 1773-1776. Richmond, VA: Virginia State Library.

Kennedy, J. P. (ed.) 1906a Journals of the House of Burgesses of Virginia, 1766-1769. Richmond, VA: The Colonial Press, Everett Waddey Company.

Kennedy, J. P. (ed.) 1906b. Journals of the House of Burgesses of Virginia, 1770-1772. Richmond, VA: The Colonial Press, Everett Waddey Company.

Kennedy, J. P. (ed.) 1907. Journals of the House of Burgesses of Virginia, 1761-1765. Richmond, VA: The Colonial Press, Everett Waddey Company.

Labaree, L. W. (ed.) 1966. The Papers of Benjamin Franklin, Vol. 9. New Haven, CT: Yale University Press.

Lee, R. H. 1825. The Memoir of the Life of Richard Henry Lee and His Correspondence, Vol. 1. Philadelphia: H. C. Carey and I. Lee.

Mays, D. J. 1952. Edmund Pendleton, 1721-1803: A Biography, Vol. 1. Cambridge, MA: Harvard University Press.

Mays, D. J. 1967. The Letters and Papers of Edmund Pendleton, 1734-1803, Vol. 1. Charlottesville, VA: University of Virginia Press.

McCusker, J. J. 1978. Money and Exchange in Europe and America, 1600-1775. Chapel Hill, NC: University of North Carolina Press.

Mcllwaine, H. R. (ed.) 1908. Journals of the House of Burgesses of Virginia, 1758-1761. Richmond, VA: The Colonial Press, Everett Waddey Company.

McIlwaine, H. R. (ed.) 1909. Journals of the House of Burgesses of Virginia, 1752-1755, 1756-1758. Richmond, VA: The Colonial Press, Everett Waddey Company.

Newman, E. P. 2008. The Early Paper Money of America. Iola, WI: Krause Publications, (5 ${ }^{\text {th }}$ edition).

William and Mary College Quarterly Historical Magazine (Apr. 1912), v. 20, no. 4, pp. 227-262. 